UNIVERSITE DE LAUSANNE - FACULTE DE BIOLOGIE ET DE MEDECINE Département de gynécologie-obstétrique et génétique médicale

Birth records from Swiss married couples analyzed over the past 35 years reveal an aging of first-time mothers by 5.1 years while the interpregnancy interval has shortened

\title{
THESE
}

préparée sous la direction du Professeur D. de Ziegler (avec la co-direction du Professeur P. Hohlfeld)

et présentée à la Faculté de biologie et de médecine de l'Université de Lausanne pour l'obtention du grade de

DOCTEUR EN MEDECINE

par

\section{Urs KALBERER}

MQ

\section{Lausanne}


- I Université de Lausanne

Faculté de biologie et de médecine

\section{Ecole Doctorale} Doctorat en médecine

\section{Imprimatur}

Vu le rapport présenté par le jury d'examen, composé de

Directeur de thèse

Co-Directeur de thèse

Expert

Directrice de l'Ecole doctorale
Monsieur le Professeur Dominique De Ziegler

Monsieur le Professeur Patrick Hohlfeld

Madame le Professeur Brigitte Santos-Eggimann

Madame le Professeur Stephanie Clarke

la Commission MD de l'Ecole doctorale autorise l'impression de la thèse de

\section{Monsieur Urs Kalberer}

intitulée

Birth records from Swiss married couples analyzed over the past 35 years reveal an aging of first-time mothers by 5.1 years while the interpregnancy interval has shortened

Lausanne, le 30 novembre 2011

pour Le Doyen

de la Faculté de Biologie et de Médecine

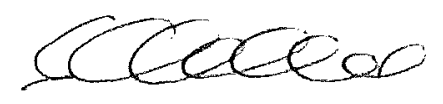

Madame le Professeur Stephanie Clarke Directrice de l'Ecole doctorale 


\section{Résumé}

Introduction : Le travail de thèse est un article publié dans le journal « Fertility \& Sterility " s'intitulant "Birth records from Swiss married couples analyzed over the past 35 years reveal an aging of first-time mothers by 5.1 years while the interpregnancy interval has shortened $"$.

Méthodes: Les données concernant l'âge auquel les femmes mariées donnaient naissance ont été obtenues de l'Office fédéral de la statistique. Nous avons examiné la période allant de 1969 à 2006. Cet intervalle de temps choisi nous a permis de prendre en considération un total de $2^{\prime} 716^{\prime} 370$ naissances. L'âge moyen des parturientes à la naissance de leur $1^{\mathrm{er}}, 2^{\text {ème }}$ et $3^{\text {ème }}$ enfant a été calculé pour chaque année à l'aide du logiciel Excel. Grâce à ces données on a pu obtenir les intervalles inter-gestationnels théoriques entre le $1^{\text {er }}$ et $2^{\text {ème }}$ enfant, ainsi qu'entre le $2^{\text {ème }}$ et $3^{\text {ème }}$ enfant.

Résultats : Nous pouvons constater que l'intervalle inter-gestationnel théorique entre la première et la deuxième grossesse était de 23.2 mois en 1969 et passait à 13.0 mois en 2006. L'intervalle compris entre la deuxième et la troisième grossesse passait de 22.4 mois en 1969 à 7.9 mois en 2006. Notre analyse suggère donc que c'est le facteur social qui exerce un effet plus important que le facteur biologique sur les intervalles inter-gestationnels, car ces intervalles diminuaient malgré l'augmentation de l'âge des mères à la naissance. 


\title{
Birth records from Swiss married couples analyzed over the past 35 years reveal an aging of first-time mothers by 5.1 years while the interpregnancy interval has shortened
}

\begin{abstract}
Although the general trend for delaying childbearing is generally viewed as causing infertility, its consequences on the interpregnancy interval have been unknown. A study of birth records for Swiss married women from 1969 to 2006 revealed that the woman's age at first birth has increased from 25.0 to 30.1 years, whereas calculated theoretical interpregnancy intervals after the first and second child decreased from 23.2 to 13 and from 22.4 to 7.9

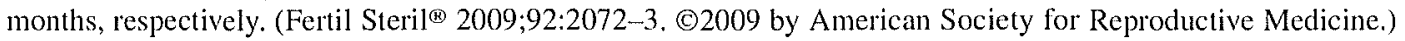

Key Words: Aging, delaying childbearing, fertile couples, interpregnancy interval

Over the last 3 decades, a general trend for delaying childbearing has been observed in all industrialized countries (1), which is generally viewed as a possible cause of infertility (2). The consequences that this trend may have on the interpregnancy interval (IPI) have been far less clear, however. As women are having their first child later in life, we reckon that two primary factor's stand to exert opposite effects on the first-to-second and the second-to-third birth intervals. [1] An age-related decrease in fecundity could increase the between-child interval, as time to conception might lengthen. [2] Conversely, delaying the first birth is likely to increase the urge for a new conception as time for completing the family project dwindles (3), which will tend to shorten the between-births interval.

To determine which of these two factors prevails in practice, we analyzed the trend seen in women's ages at the first, second, and third births from the birth records of married couples in Switzerland from 1969 to 2006 (35 years) (4). Limiting the search to mar-

Urs Kalberer, M.D."

David Baud, M.D., Ph.D."

Amaud Fontanet, M.D., Ph.D."

Patrick Hohlfeld, M.D."

Dominique de Ziegler, M.D. ${ }^{\text {a,c }}$

"Department of Obstetrics and Gynecology, University Hospital of Lausame, Maternity, CHUV, Lausame, Switzerland

${ }^{b}$ Emerging Diseases Epidemiology Unit, Institut Pasteur de Paris, Paris, France

'Department of Obstetrics and Gynecology' II, GHU Cochin St. Vincent de Paul, Université Paris Descartes, Paris, France

Received February 10, 2009; revised May 7, 2009; accepted May 22, 2009; published online July 15, 2009.

U.K. has nothing to disclose. D.B. has nothing to disclose. A.F. has nothing to disclose. P.H. has nothing to disclose. D.D. has nothing to disclose.

Reprint requests: Dominique de Ziegler, M.D., Professor and Head, Reproductive Endocrine and Infertility, Department of Obstetrics and Gynecology II, Hôpital Cochin-St Vincent de Paul, $82 \mathrm{Bd}$ Denfert-Rocherau, 75014 Paris, France (FAX: 41-22-382-4313; E-mail: ddeziegler@orange.fr). ried couples minimized the possibility of confounding effects from incidental events such as separations and divorces.

Birth records were obtained from the Swiss Federal Office of Statistics (4), which provides publicly available data. A total of $2,716,370$ births from married women were included. The mean age of the women at the birth of their first, second, and third child was computed yearly between 1969 and 2006. For each time point, theoretical IPI data - defined as the lapsed time between past birth and new conception - were extrapolated from the women's ages at the deliveries of their first, second, and third children, accounting for a mean gestation time of 9 months.

For the purposes of information, the trend observed in the percentage of births occurring in married couples over the total number of births and the crude birth rate, expressed as the number of births per 1000 inhabitants, were provided for the observation period. The statistical significance of the longitudinal changes in age at birth and IPIs were assessed using a nonparametric test for trends (Cuzick). Percentages and $P$ values were calculated using STATA 9.0 (College Station, TX).

As illustrated in Figure $1 \mathrm{~A}$, the age of Swiss married women at the birth of their first child increased from 25.0 years in 1969 to 30.1 years in $2006(P<.001)$. The actual number of births of first, second, and third children were of $41,495,32,626$, and 14,158 per year, respectively, at the onset of the observation period in 1969. During the observation period, these numbers progressively decreased by $29 \%, 28 \%$, and $49 \%$, respectively, to $29,477,22,322$, and 7192 births of first, second, and third children in 2006. This reflected a decline in the crude birth rate from 16.0 per 1000 to 9.9 per 1000 inhabitants/year $(P<.001)$. Theoretical IPIs are depicted in Figure 1B. From these calculations, the theoretical IPI decreased by $32 \%$ and $46 \%$, respectively, after the first and second children during the observation period $(P<.001)$. In 1969, theoretical IPIs ware of 23.2 and 22.4 months after the first and second children, respectively, whereas in 2006 these numbers dropped to 13 and 7.9 months, respectively.

Our analysis of birth records in Swiss married couples between 1969 and 2006 confirmed the significant aging of first-time mothers that has been observed in all industrialized countries over the last 3 decades (2). In the studied population, this phenomenon was 
(A) Maternal age at birth of first, second, and third child from 1969 to 2006. (B) Theoretical interpregnancy interval (IPI) after first and second child from 1969 to 2006.

A

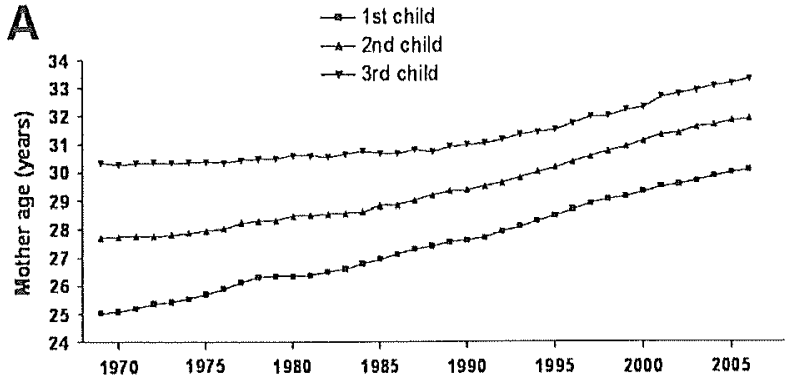

\section{$B$}

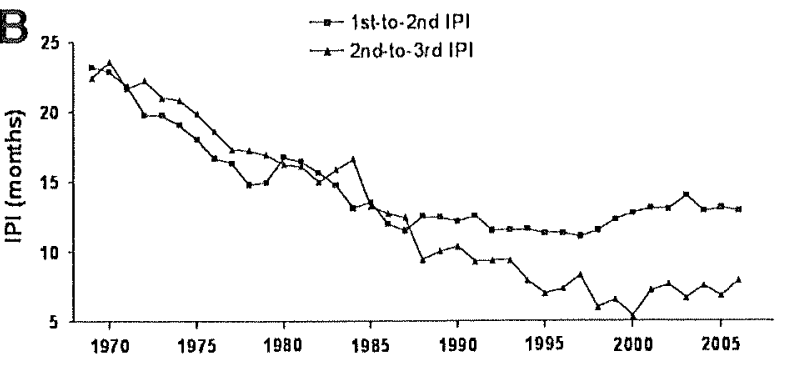

Kalberes: Correspondence. Fertil Steril 2009.

associated with a parallel shortening of the mean theoretical IPI after the first and second child-computed from women's ages at first, second, and third births-by $32 \%$ and $46 \%$, respectively $(P<.001)$.
Our birth record analysis suggests therefore that the postponement of first-time birth observed between 1969 and 2006 was actually associated with a shortening of IPI. This indicates that the increased urge of completing the family project as a result of delaying childbearing has more impact on maternal age at second and third births than any possible lengthening of conception time as a result of decreased fecundity.

Our data are in line with the observations of Nabukera et al. (5), whose population-based study observed shorter IPIs of 25.3 months for mothers in whom the first birth took place between the ages of 30 to 34 years, as compared with 30.7 months for first-time mothers aged 20 to 29 years (5).

One limitation of our study was that our analysis, based on a national registry of birth records, computed theoretical IPIs that were means of the population, not individual IPIs. Actual IPIs might actually be different, as at any given time point the mothers who delivered their second and third child may have had their first birth at an earlier age than predicted by the mean age of first births at that particular time. An other limitation is that our computation of IPI accounted for a theoretical gestational time of 9 months, but some pregnancies might have been shorter. However, considering the relatively large numbers involved, it can be assumed that these data adequately represent a trend.

Our analysis of birth data in Swiss married couples suggests that delaying child bearing is associated with a shortening of IPIs after the second and third child. Medical personnel should be aware of this little-publicized consequence of delaying childbearing so that they can provide appropriate counseling to women who have recently delivered and are considering more pregnancies, because too-short IPIs may adversely affect maternal and neonatal outcome (6).

\section{REFERENCES}

1. Schwartz D, Mayaux MJ. Female fecundity as a function of age: results of artificial insemination in 2193 nulliparous women with azoospermic husbands. Federation CECOS. N Engl J Med 1982;306:404-6.

2. Rowe T. Fertility and a woman's age. J Reprod Med 2006;51:157-63
3. Rao KV, Balakrishnan TR. Timing of first birth and second bith spacing in Canadia. J Biosoc Sci 1989;21:293-300.

4. Swiss Federal Statistical Office Swiss Statistics Web site. Available at http://www.bfs.admin.ch/bfs/portal/ en/index.html. Accessed June 6. 2009.
5. Nabukera SK, Wingate MS. Salihu HM, Owen J, Swaminathan S, Alexinder GR, Kirby RS. Pregnancy spacing among women delaying initiation of childbearing. Arch Gynecol Obstet 2008;279;677-84.

6. Conde-Agudelo A, Rosus-Bermudez A, KafuryGoeta AC. Birth spacing and risk of adverse perinatal outcomes: at meta-analysis. JAMA 2(0)6;295: 1809-23. 


\section{Rapport de synthèse}

\section{$\underline{\text { Introduction }}$}

Le travail de thèse est un article publié dans le journal "Fertility \& Sterility " s'intitulant "Birth records from Swiss married couples analyzed over the past 35 years reveal an aging of first-time mothers by 5.1 years while the interpregnancy interval has shortened $"$.

Dans ce travail nous nous référons tout d'abord aux données statistiques des trois dernières décennies. Selon ces données, le monde industrialisé a connu une augmentation graduelle de l'âge moyen auquel les femmes donnaient naissance à leurs enfants.

Ce phénomène qui touche principalement les pays industrialisés est bien connu. Toutefois, les conséquences de ce développement sur l'intervalle entre deux grossesses n'ont pas encore été étudiées.

\section{Outils théoriques}

Pour appréhender notre problématique, nous avons émis l'hypothèse de recherche selon laquelle deux facteurs primaires influenceraient de manière opposée l'intervalle entre deux grossesses.

II s'agit tout d'abord du facteur biologique. Celui-ci tend à augmenter l'intervalle intergestationnel, selon le lien confirmé qui existe entre l'âge maternel croissant et la diminution de la fertilité. Dans un deuxième temps, nous devons considérer le facteur social qui, l'âge avançant, tend à exercer une certaine pression sur les couples souhaitant réaliser leur projet de procréation.

\section{Outils pratiques : échantillon, procédés d'analyse et d'évaluation}

Pour mener à bien notre étude, nous avons eu recours aux données provenant de l'Office fédéral de la statistique concernant l'âge auquel les femmes donnaient naissance. Nous avons examiné la période allant de 1969 à 2006. L'intervalle de temps choisi nous a permis de prendre en considération un total de 2'716'370 naissances. II convient de préciser qu'il s'agit uniquement des naissances survenues chez les femmes mariées. Nous avons choisi cette approche dans le but de minimiser d'autres facteurs, tels que les séparations ou les divorces, susceptibles de prêter à confusion. L'analyse statistique a ensuite été effectuée en utilisant les logiciels Excel (pour calculer l'âge moyen des parturientes pour chaque année entre 1969 et 2006) et STATA 9.0 (pour calculer les valeurs p ou de signifiance statistique). Grâce à ce procédé, nos résultats peuvent être considérés comme significatifs comme en témoigne un $" p$ » de $<0.001$. En statistique, cette valeur est considérée comme étant très significative. 


\section{Évaluation : limites de notre procédé}

Les valeurs d'intervalles inter-gestationnels obtenues ne reflètent pas forcément la réalité, puisque que nous nous sommes basés sur une durée de grossesse de neuf mois pour effectuer notre calcul de base. Or nous savons qu'en réalité la durée d'une grossesse peut être considérée sur un laps de temps plus court ou plus long que neuf mois. De plus, vu que les valeurs d'âge maternel à la naissance sont des valeurs moyennes, les intervalles inter-gestationnels ainsi calculé ne correspondent pas complètement à la réalité. Subséquemment, les femmes ayant eu leur premier enfant à un très jeune âge et ayant eu leur deuxième enfant à un âge très tardif ne contribueront donc pas à augmenter l'intervalle inter-gestationnel théorique, tandis que c'est le cas pour l'intervalle inter-gestationnel réel.

Toutefois, le nombre de cas considéré est très large, limitant ainsi les erreurs. Les résultats obtenus représentent donc une réelle tendance.

\section{Résultats de notre étude}

Au vu des résultats obtenus à l'issue de notre étude, nous pouvons constater que l'intervalle inter-gestationnel théorique entre la première et la deuxième grossesse était de 23.2 mois en 1969 et passait à 13.0 mois en 2006. L'intervalle compris entre la deuxième et la troisième grossesse passait de 22.4 mois en 1969 à 7.9 mois en 2006.

Notre analyse suggère donc que le facteur social prime sur le facteur biologique.

Par conséquent, le corps médical doit être informé qu'une diminution de l'intervalle entre 2 grossesses s'est produite durant les trois dernières décennies. En effet, un intervalle inter-gestationnel trop court est généralement associé à une augmentation des risques de complications obstétricales.

\section{Publication}

Il convient également de noter que l'article sous-tendant cette synthèse a été publié dans "Fertility \& Sterility ». II s'agit d'un mensuel de portée internationale ayant un « impact factor » de 3,97 . 